\title{
Comparison of pre-operative ultrasonography and magnetic resonance cholangiopancreatography with intra-operative surgical findings among patients suspicious to choledocholithiasis.
}

Pulak Kumar Samanta ( $\sim$ pulakkrsamanta2014@gmail.com ) BSMCH,WB,India

Sabyasachi Bakshi

BSMCH,WB,India https://orcid.org/0000-0002-6475-0914

\section{Research Article}

Keywords: Choledocholithiasis, Ultrasonography, MRCP, Obstructive Jaundice

Posted Date: May 13th, 2020

DOI: https://doi.org/10.21203/rs.3.rs-28553/v1

License: (c) (1) This work is licensed under a Creative Commons Attribution 4.0 International License. Read Full License 


\section{Abstract}

BACKGROUND: Choledocholithiasis with cholelithiasis is a common problem in the middle and older age group people. Aim of this study is to assess the usefulness of ultrasonography in the diagnosis of choledocholithiasis in resource poor set up.

METHODS: After matching the inclusion and exclusion criteria, all cases of diagnosed Choledocholithiasis were taken for this prospective, single center, observational study.

RESULTS: Out of total 130 subjects, 41 were male and 89 were female. Increased incidence of choledocholithiasis was found in females (M: $F=1: 2.08)$. The mean age of presentation was $49.27 \pm$ 10.60 years. Ultrasonography was able to diagnose CBD stones in 57patients (43.84\%) and ductal dilatation in 89(68.46\%). Whereas, MRCP detected CBD stones in $112(86.15 \%)$. Cholelithiasis was associated with choledocholithiasis in 108 patients (83.07\%).

CONCLUSIONS: In the evaluation of choledocholithiasis, in our study particularly trans-abdominal USG seemed to have a lower yield than expected for accuracy in determining choledocholithiasis when compared to MRCP and Intra-operative findings. So a negative USG in a particular may not exclude choledocholithiasis. So,MRCP is the 'investigation of choice' among the suspicious patients for CBD stone disease. That is why prior to cholecystectomy in symptomatic patients with deranged LFT, MRCP always to be done, to detect the missed stone in CBD.

\section{Introduction}

Choledocholithiasis with cholelithiasis is a common problem in middle and older age group of our society both in rural and urban areas. The ocurrence of choledocholithiasis in patients with cholelithiasis varies from $5 \%$ to $15 \%$,among only them $5 \%$ are symptomless. ${ }^{1,2}$ Though biliary calculus formation is seen in all age groups, but it is the 'fat, flatulent, fertile, female of fifty' who are commonly affected. Number of documented cases of choledocholithiasis is continuously increasing in the developing countries owing partly to the availability of improved imaging facilities ${ }^{3}$.The majority of common bile duct stones is formed within the gallbladder and then migrates down through the cystic duct to common bile duct $^{4}$.According to the site of formation of common bile duct stones, it is of two types; primary stones(found rarely) which is formed in bile duct and secondary CBD(Common Bile Duct) stones, which passes into the common bile duct through cystic duct. Studies have shown that the biliary tract stones were complicated by concomitant gallstones in $15-20 \%$ of patients ${ }^{5}$. It was estimated that $3-33 \%$ of all patients with symptomatic cholelithiasis harbor concomitant CBD stones ${ }^{6}$. and in $4-20 \%$ subjects, CBD stones are detected incidentally during cholecystectomy ${ }^{6}$.The incidence of choledocholithiasis in patients with cholelithiasis increases with age. Cholelithiasis is also more common in those with high serum lipid levels. Obese patients,subjects with low physical activity, patients with recent weight loss are found to have cholesterol stones. Black pigment stones are mainly seen in subjects with cirrhosis of liver, total 
parental nutrition reciepients, and in patients with ileal resection. Brown pigment primary common bile duct calculus has nucleating factors, such as bacteria, as their source. ${ }^{7}$

Usually patients may complain of colicky pain, intermittent jaundice, pruritus, vomiting and dyspepsia. But these choledocholithiasis patients may develop some serious complications like- cholangitis and acute pancreatitis and are associated with high morbidity and mortality. So, early detection and management of choledocholithiasis are essential. The detection of choledocholithiasis is usually done in clinically suspected patient by biochemical analysis (raised conjugated bilirubin, alkaline phosphatase and gamma-glutamyl transpeptidase level) and with the help of certain imaging modalities. Diagnostic imaging tests for choledocholithiasis include trans-abdominal ultrasonography(USG), Magnetic Resonance Cholangiopancreatography(MRCP), Multi Detector Computed tomography(MDCT), Cholangiography, endoscopic ultrasonography(EUS) and Endoscopic retrograde cholangiopancreatography(ERCP).

Trans-abdominal USG is the most commonly used primary imaging modality. It is non-invasive, widely available, low cost, non-ionizing radiation imaging technique. Specificity of USG to detect common bile duct stone is up to $95 \% .{ }^{8}$ But it is operator dependent, and it has a limitation in patients those with large amount of bowel gas and obesity. Trans-abdominal ultrasonography scans and liver function tests fail to accurately identify common bile duct calculus. Magnetic Resonance Cholangiopancreatography(MRCP) is the next imaging modality in case of any uncertainty with USG. MRCP was introduced by Wallner et al in 1991. They used the rapid sequence gradient echo acquisition with three-dimensional post processing technique to evaluate the biliary system. MRCP has providing high resolution images of biliary tree non-invasively and does not require any contrast media ${ }^{9}$. Presently, MRCP is being considered as more accurate and convenient imaging method for the diagnosis of choledocholithiasis. ${ }^{10}$

After confirming the diagnosis of choledocholithiasis, the prime modalities of treatment of common bile duct stones are ERCP extraction(in selected cases) or exploration of common bile duct by laparoscopic or open surgical approach. When endoscopic technique failed or not feasible for the patient, choledochotomy is the best mode of treatment either by open approach or laparoscopic method.Many factors that have determined the optimal approach include variables such as disease status, unavailability of radiological facility and endoscopic and surgical expertise, patient's demographic and health care economics.

The aim of the present study is to compare the diagnostic efficacy between USG, MRCP with intraoperative findings in detection and characterization in patients with choledocholithiasis.So that,USG can be effectively used in resource poor setting where Intra-Operative cholangiogram or ERCP facilities are not available.In this study, the common hepatic duct and the common bile duct were considered as one structure, the common duct. The common duct is dilated when the calibre is $8 \mathrm{~mm}$ and more. The 
diagnosis of choledocholithiasis was made when an intraluminal echogenic focus with acoustic shadowing was demonstrated ${ }^{11}$.

In this study,intra-operative demonstration of CBD stones and duct diameter was considered the "gold standard".In this study evaluation of the results of USG and MRCP and their correlation with surgical findingsof choledocholithiasis were assessed. The sensitivity, specificity and predictive values of USG and MRCP as preoperative investigation were also evaluated.

\section{Methods}

This is an institution based (single center) prospective, observational hospital based, comparative, cross sectional study. The study included 130 patients, who attended OPD from March 2018 to August 2019 in general surgery department of BSMCH medical college. They were suspected of having choledocholithiasis(on the basis of any of the following parameters such as:pain at right hypochondrium and epigastric area, intermittent jaundicestatus of post biliary pancreatitis, total bilirubin $>1.2 \mathrm{mg} / \mathrm{dl}$ and/ or ALP>220 IU/L , CBD stone suspected/diagnosed at sonography, CBD diameter at sonography $>7 \mathrm{~mm}$, CBD diameter at MRCP $>7 \mathrm{~mm}$ or $\mathrm{CBD}$ stone suspect/ diagnosed at MRCP.)

All cases of obstructive jaundice where the cause proved to be other than CBD stones were excluded from the study.

Inclusion criteria for this study wereas following: Both male \& female individuals of age more than 11 years, who themselves or their legal guardians consented for surgery and do not like to undergo ERCP.

Subjects should be fit to receive general anaesthesia.

Exclusion criteria were : Patients less than 11 years,who are willing to undergo ERCP and unfit for general anesthesia. Patients with contraindication to perform MRI were also excluded.

\section{Study procedure:}

All the patients presented with pain at right hypochondrium and epigastric region, intermittent jaundice with/without fever, history of previous biliary pancreatitis were subjected to blood tests. Liver function test and Tans-abdominal USG were done. Those with no positive finding suggestive of choledocholithiasis were excluded from the study. The subjects with dilated CBD $(>7 \mathrm{~mm})$ with or without CBD calculus, with increased total Bilirubin level \& increased ALP level were considered for the study. All of them were evaluated with MRCP study. Those with choledocholithiasis on MRCP were directly taken for CBD exploration.

All those who were negative for CBD calculus on MRCP were taken for open cholecystectomy and CBD palpation was done intraoperatively. Subjects having CBD calculus on palpation got their CBD explored. 
The subjects who were negative for CBD calculus both on MRCP and palpation were subjected to cholecystectomy only. Parameters such as age, Gender, severity of obstructive jaundice, Characteristics of the CBD stones ( present /absent), position of stones (proximal/ distal/ ampullary), number of stones ( single/ multiple) and dilatation of $\mathrm{CBD}(<7 \mathrm{~mm} />=7 \mathrm{~mm})$, size of stones were also studied.

Questionnaire for interview/ proforma or checklist for clinical examination to collect baseline data, biochemical reports, and reports of ultrasonography \& MRCP study were used as study tools.

The statistical analysis was carried out using available standard statistical software(SPSS-23). Odds ratio with $95 \%$ confidence interval $(\mathrm{Cl})$ and multivariate analysis has used establish the interrelationships between pre-operative and intra operative findings. All statistical tests has two tailed and $P$ value $<0.05$ has taken as significant.

\section{Results}

\section{Patients' Demographics:}

The study comprised 130 patients with suspected to choledocholithiasis who underwent Liver function test, Trans-abdominal USG and MRCP. Age distribution in the present study was found to be from $25 \mathrm{yrs}$ to $71 \mathrm{yrs}$, the mean age of patients was $49.27 \pm 10.60$ years, out of 130 patients, 89 patients were female and 41 patients were male, the ratio of male: female was 1:2.08.

Table 1:Distribution of participants according to gender\& present of cbd stone $(n=130)$

\begin{tabular}{llll}
\hline SEX & CBD STONE FOUND $(+)$ & CBD STONE NOT FOUND $(-)$ & TOTAL \\
& No. $(\%)$ & No. $(\%)$ & No. $(\%)$ \\
\hline MALE & $37(28.46 \%)$ & $04(3.08 \%)$ & $41(31.54 \%)$ \\
\hline FEMALE & $77(59.23 \%)$ & $12(9.23 \%)$ & $89(68.46 \%)$ \\
\hline TOTAL & $114(87.69 \%)$ & $16(12.31 \%)$ & $130(100 \%)$
\end{tabular}


Distribution of participants according to age $(n=130)$

\begin{tabular}{llll}
\hline Age group & Male, $\mathrm{n}(\%)$ & Female,n(\%) & Total, $\mathrm{n}(\%)$ \\
\hline $21-30$ & $03(02.30)$ & $09(06.92 \%)$ & $12(09.0 \%)$ \\
\hline $31-40$ & $04(03.08)$ & $10(07.69 \%)$ & $14(11.0 \%)$ \\
\hline $41-50$ & $16(12.30)$ & $35(26.92 \%)$ & $51(38.9 \%)$ \\
\hline $51-60$ & $10(07.70)$ & $21(16.16 \%)$ & $31(24.0 \%)$ \\
\hline$>60$ & $08(06.16)$ & $14(10.77 \%)$ & $22(17.1 \%)$ \\
\hline TOTAL & $41(31.54 \%)$ & $89(68.46 \%)$ & $130(100 \%)$ \\
\hline
\end{tabular}

Table1, shows common bile duct stones are more common in female than male and male:female ratio is 1:2.08. This table reveals age specific distribution of choledocholithiasis among study participants,female were more than male in each group of age and the disease is common in 41-50 age group. The mean age is $49.27 \pm 10.60$ years(range $25-71$ Yrs)

Clinical profile and Laboratory investigation of patients: 
TABLE 2: DISTRIBUTION OF PARTICIPANTS AS PER TOTAL BILIRUBIN LEVEL ANDCBD STONES FINDINGS.

\begin{tabular}{|c|c|c|c|c|c|c|}
\hline \multirow[t]{2}{*}{$\begin{array}{l}\text { Age } \\
\text { gr }\end{array}$} & \multirow[t]{2}{*}{ Gender } & \multirow{2}{*}{$\begin{array}{l}<2.41 \\
\mathrm{mg} / \mathrm{dl} \\
\text { No. (\%) }\end{array}$} & \multirow{2}{*}{ 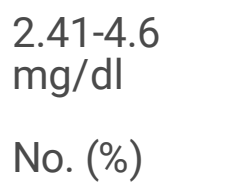 } & \multirow{2}{*}{$\begin{array}{l}>4.6 \mathrm{mg} / \mathrm{dl} \\
\text { No. (\%) }\end{array}$} & \multirow{2}{*}{$\begin{array}{l}\text { Total } \\
\text { No. (\%) }\end{array}$} & \multirow[t]{2}{*}{$\begin{array}{l}\text { CBD stone found, } n \\
(\%)\end{array}$} \\
\hline & & & & & & \\
\hline \multirow[t]{2}{*}{$21-30$} & Male & $1(0.77 \%)$ & $3(2.31 \%)$ & $1(0.77 \%)$ & $5(3.85 \%)$ & $3(2.63 \%)$ \\
\hline & Female & $5(3.84 \%)$ & - & $4(3.08 \%)$ & $9(6.92 \%)$ & $7(6.14 \%)$ \\
\hline \multirow[t]{2}{*}{$31-40$} & Male & $2(1.54 \%)$ & - & - & $2(1.54 \%)$ & $3(2.63 \%)$ \\
\hline & Female & $4(3.08 \%)$ & $8(6.15 \%)$ & $2(1.54 \%)$ & $14(10.77 \%)$ & $10(8.77 \%)$ \\
\hline \multirow[t]{2}{*}{$41-50$} & Male & $3(2.31 \%)$ & $8(6.15 \%)$ & $7(5.38 \%)$ & $18(13.84 \%)$ & $16(14.04 \%)$ \\
\hline & Female & $8(6.15 \%)$ & $18(13.85 \%)$ & $4(3.08 \%)$ & $30(23.08 \%)$ & $29(25.44 \%)$ \\
\hline \multirow[t]{2}{*}{$51-60$} & Male & - & $6(4.62)$ & $4(3.08 \%)$ & $10(7.70 \%)$ & $8(7.02 \%)$ \\
\hline & Female & $5(3.85 \%)$ & $7(5.38 \%)$ & $8(6.15 \%)$ & $20(15.38 \%)$ & $19(16.67 \%)$ \\
\hline \multirow[t]{2}{*}{$>60$} & Male & - & $1(0.77 \%)$ & $5(3.64 \%)$ & $6(4.61 \%)$ & $6(5.26 \%)$ \\
\hline & Female & $2(1.54 \%)$ & $3(2.31 \%)$ & $11(8.46 \%)$ & $16(12.31 \%)$ & $13(11.40 \%)$ \\
\hline Total & & $30(23.08 \%)$ & $54(41.54 \%)$ & $46(35.58 \%)$ & 130(100\%) & $114(100 \%)$ \\
\hline
\end{tabular}


DISTRIBUTION OF PARTICIPANTS AS PER SERUM ALKALINE PHOSPHATASE LEVEL WITH CBD STONE FINDINGS.

\begin{tabular}{|c|c|c|c|c|c|}
\hline Age gr. & Gender & $<235$ IU/L n,(\%) & $>=235$ IU/L n,(\%) & Total, n (\%) & CBDst0ne found, $\mathrm{n}(\%)$ \\
\hline \multirow[t]{2}{*}{$21-30$} & Male & $2(1.54 \%)$ & $1(0.77 \%)$ & $3(2.31 \%)$ & $3(2.63 \%)$ \\
\hline & Female & $3(2.31 \%)$ & $6(4.62 \%)$ & $9(6.92 \%)$ & $7(6.14 \%)$ \\
\hline \multirow[t]{2}{*}{$31-40$} & Male & $2(1.54 \%)$ & $5(3.85 \%)$ & $7(5.39 \%)$ & $3(2.63 \%)$ \\
\hline & Female & $2(1.54 \%)$ & $9(6.92 \%)$ & $11(8.46 \%)$ & 10(8.77\%) \\
\hline \multirow[t]{2}{*}{$41-50$} & Male & $3(2.31 \%)$ & $8(6.15 \%)$ & $11(8.46 \%)$ & $16(14.04 \%)$ \\
\hline & Female & $12(9.23 \%)$ & $24(18.46 \%)$ & $36(27.69 \%)$ & $29(25.44 \%)$ \\
\hline \multirow[t]{2}{*}{$51-60$} & Male & $2(1.54 \%)$ & $8(6.15 \%)$ & $10(7.69 \%)$ & $8(7.02 \%)$ \\
\hline & Female & $5(3.84 \%)$ & $16(12.31 \%)$ & $21(16.16 \%)$ & $19(16.67 \%)$ \\
\hline \multirow[t]{2}{*}{$>60$} & Male & $2(1.54 \%)$ & $6(4.62 \%)$ & $8(6.15 \%)$ & $6(5.26 \%)$ \\
\hline & Female & $1(0.76 \%)$ & $13(10.00 \%)$ & $14(10.77 \%)$ & $13(11.40 \%)$ \\
\hline Total & & $34(26.15 \%)$ & $96(73.85 \%)$ & $130(100 \%)$ & $114(100 \%)$ \\
\hline
\end{tabular}

Table2 shows mean total bilirubin level is $3.50 \pm 1.36 \mathrm{mg} / \mathrm{dl}$ ( range 1.02-7.04). Serum total bilirubin level was raised above $1.21 \mathrm{mg} / \mathrm{dl}$ except one case bilirubin is $1.02 \mathrm{mg} / \mathrm{dl}$.Mean Alkaline Phosphatase level is $381.56 \pm 219.684 \mathrm{IU} / \mathrm{L}$ (range $156.04-1304.15)$ in this study. 96 out of 130 serum alkaline phasphatase level were $>235 \mathrm{IU} / \mathrm{L}$ 
TABLE 3:DISTRIBUTION OF PARTICIPANTS AS PER CBD STONES DETECTED BY USG (TRANSABDOMINAL), MRCP and CBD STONES DETECTED DURING INTRA-OPERATIVE PERIOD.

\begin{tabular}{|c|c|c|c|}
\hline \multirow{3}{*}{ SEX } & \multicolumn{2}{|l|}{ USG } & \multirow[b]{2}{*}{ TOTAL } \\
\hline & STONE DETECTED IN CBD & STONE NOT DETECTED IN CBD & \\
\hline & No. (\%) & No. (\%) & No. (\%) \\
\hline MALE & $18(13.85 \%)$ & $23(17.69 \%)$ & $41(31.54 \%)$ \\
\hline FEMALE & $39(30.00 \%)$ & $50(38.15 \%)$ & $89(68.46 \%)$ \\
\hline TOTAL & $57(43.85 \%)$ & 73(56.15\%) & $130(100 \%)$ \\
\hline
\end{tabular}

\begin{tabular}{llll} 
Gender & MRCP & \\
\cline { 2 - 4 } & CBD stone present n.(\%) & CBD stone absent n.(\%) & Total n. (\%) \\
\hline Male & $36(27.69 \%)$ & $5(3.85 \%)$ & $41(31.54 \%)$ \\
\hline Female & $76(58.46 \%)$ & $13(10.00 \%)$ & $89(68.46 \%)$ \\
\hline Total & $112(86.15 \%)$ & $18(13.85 \%)$ & $130(100 \%)$
\end{tabular}

\begin{tabular}{llll} 
Gender & Intra-operative & & \\
\cline { 2 - 4 } & CBD stone present,n(\%) & CBD stone absent,n(\%) & Total \\
\hline Male & $36(27.69 \%)$ & $05(3.85 \%)$ & $41(31.54 \%)$ \\
\hline Female & $78(60.00 \%)$ & $11(8.46 \%)$ & $89(68.46 \%)$ \\
\hline Total & $114(87.69 \%)$ & $16(12.31 \%)$ & $130(100 \%)$
\end{tabular}

Table 3 shows, trans-abdominal USG detected only $43.85 \%$ CBS stones..112 out of $130(86.15 \%)$ CBD stones detected by MRCP. 114 out of 130 (87.69\%) CBD stones detected during Intra-operative period. 
TABLE 4 : DISTRIBUTION OF PARTICIPANTS AS PER CBD DAIMETER.[n=130] and AS PER POSITION OF CBD STONES IN DIFFERENT STAGES OF EVALUATION

\begin{tabular}{llll} 
Different stages of evaluation & \multicolumn{2}{l}{ CBD diameter } & \multirow{2}{*}{ Total No.(\%) } \\
\cline { 2 - 3 } & $<7 \mathrm{~mm}$ & $\geq 7 \mathrm{~mm}$ & \\
& No. $(\%)$ & No. $(\%)$ & \\
\hline CBD Diameter on USG & $41(31.54 \%)$ & $89(68.46 \%)$ & $130(100 \%)$ \\
\hline CBD Diameter on MRCP & $6(4.61 \%)$ & $124(95.39 \%)$ & $130(100 \%)$ \\
\hline CBD Diameter Intra-Operative & $7(5.39 \%)$ & $123(94.61 \%)$ & $130(100 \%)$
\end{tabular}

\begin{tabular}{|c|c|c|c|c|}
\hline \multirow[t]{3}{*}{ FINDINGS at different stages } & \multirow{3}{*}{$\begin{array}{l}\text { Overall }(n=130) \\
\text { Number of patient } \\
\text { stone }+\end{array}$} & \multicolumn{3}{|c|}{ Subgroups } \\
\hline & & Proximal & \multirow{2}{*}{$\begin{array}{l}\text { Distal CBD } \\
\text { No. (\%) }\end{array}$} & \multirow{2}{*}{$\begin{array}{l}\text { Ampullary } \\
\text { No. (\%) }\end{array}$} \\
\hline & & & & \\
\hline Position of stone at CBD in USG & $57(43.85 \%)$ & $2(1.54 \%)$ & $55(42.31 \%)$ & - \\
\hline $\begin{array}{l}\text { Position of stone at CBD in } \\
\text { MRCP }\end{array}$ & $112(86.15 \%)$ & $3(2.31 \%)$ & $98(75.38 \%)$ & $11(8.46 \%)$ \\
\hline $\begin{array}{l}\text { Position of stone at CBD in Inrta- } \\
\text { operative. }\end{array}$ & 114(87.69\%) & $2(1.54 \%)$ & $100(76.92 \%)$ & $12(9.23 \%)$ \\
\hline
\end{tabular}


Table 4 shows,choledocholithiasis CBD were dilated due to obstruction. Distal CBD stones are most common and Ampullary stones detection by MRCP is significant.

FIGURE 1: USG AND MRCP vs intra-operative finding.

TABLE 5: USG(TRANS-ABDOMINAL) \& MRCP vS INTRA-OPERATIVE( STANDARD)

\begin{tabular}{|c|c|c|c|c|}
\hline \multicolumn{2}{|c|}{$\begin{array}{l}\text { IMAGING TESTS OF } \\
\text { CHOLEDOCHOLITHIASIS }\end{array}$} & \multicolumn{3}{|c|}{$\begin{array}{l}\text { INTRAOPERATIVE FINDINGS OF } \\
\text { CHOLEDOCHOLITHIASIS }\end{array}$} \\
\hline & & PRESENT & ABSENT & TOTAL \\
\hline & & No. (\%) & No. (\%) & No. $(\%)$ \\
\hline \multirow[t]{3}{*}{ USG } & PRESENT & $56(43.08 \%)$ & $1(0.77 \%)$ & $57(43.85 \%)$ \\
\hline & ABSENT & $58(44.61 \%)$ & $15(11.54 \%)$ & $73(56.15 \%)$ \\
\hline & TOTAL & 114(87.69\%) & $16(12.31 \%)$ & $130(100 \%)$ \\
\hline \multirow[t]{3}{*}{ MRCP } & PRESENT & $110(84.61 \%)$ & $2(1.54 \%)$ & $112(86.15 \%)$ \\
\hline & ABSENT & $4(3.08 \%)$ & $14(10.77 \%)$ & $18(13.85 \%)$ \\
\hline & TOTAL & $114(87.69 \%)$ & $16(12.31 \%)$ & $130(100 \%)$ \\
\hline
\end{tabular}

Table 5 shows, CBD stonesdetection by MRCP (84.61\%) was very high almost near to gold standard (87.69\%) but by USG it was low only $43.08 \%$. 
TABLE 6:DISTRIBUTION OF STUDY POPULATION ACCORDING TO DIFFERENT OPERATIVE PROCEDURES.

\begin{tabular}{|c|c|c|c|c|}
\hline \multicolumn{3}{|c|}{ OPERATIVE PROCEDURES } & \multicolumn{2}{|c|}{ Number of cases $(n=130)$} \\
\hline \multicolumn{3}{|c|}{ LAP GB + CBD EXPLORATION } & \multicolumn{2}{|c|}{22} \\
\hline \multicolumn{3}{|c|}{ OPEN GB + CBD EXPLORATION } & \multicolumn{2}{|c|}{82} \\
\hline \multicolumn{3}{|c|}{ CBD EXPLORATION } & \multicolumn{2}{|c|}{6} \\
\hline \multicolumn{3}{|c|}{ OPEN GB+CBD PALPATION +EXPLORATION } & \multicolumn{2}{|c|}{4} \\
\hline \multicolumn{3}{|c|}{ OPEN GB+CBD PALPATION } & \multicolumn{2}{|c|}{16} \\
\hline \multicolumn{5}{|c|}{$\begin{array}{l}\text { Distribution of participants as per trans-abdominal USG(test test) vs Intra-operative findings (gold } \\
\text { standard= truth). [130]. }\end{array}$} \\
\hline \multirow[t]{4}{*}{ USG FINDINGS } & INTRA-OPERA & & \multirow{4}{*}{$\begin{array}{l}\text { TOTAL NO. } \\
\text { (\%) }\end{array}$} & \\
\hline & $\begin{array}{l}\text { CBD STONE } \\
\text { PRESENT,NO, }\end{array}$ & $\begin{array}{l}\text { CBD STONE } \\
(\%)\end{array}$ & & df, \\
\hline & . $(\%)$ & & & \\
\hline & & & & $P$ value \\
\hline $\begin{array}{l}\text { STONE } \\
\text { PRESENT }\end{array}$ & $56(43.08 \%)$ & $1(0.77 \%)$ & $57(43.85 \%)$ & \multirow{2}{*}{$\begin{array}{l}\text { 10.47, } \\
1, \\
\text { P value } \\
=0.001\end{array}$} \\
\hline $\begin{array}{l}\text { STONE } \\
\text { ABSENT }\end{array}$ & $58(44.61 \%)$ & $15(11.54 \%)$ & $73(56.15 \%)$ & \\
\hline TOTAL & 114(87.69\%) & $16(12.31 \%)$ & $130(100 \%)$ & \\
\hline
\end{tabular}

Table 6 shows, that results of the test test ie,USG significantly differ from the truth ie,intra-operative findings. It means that the test USG didn't seem to be suitable for diagnosing the disease in question.

The sensitivity of USG was: $\quad=49.12 \%$,

$$
\text { Specificity was: } \quad=93.75 \% \text {, }
$$

Positive predictive value was; $\quad=98.25 \%$, And negative predictive value was: $=20.55 \%$. 
The sensitivity of the test USG reflected that the test seemed to be weak in detecting the disease in question ie, too many false negative would be produced by the test. For an emergency surgical problem like choledocholithiasis it couldn't be the 'investigation of choice'. As there is very effective treatment is available for choledocholithiasis we are not ready to tolerate so much false negativity of the diagnostic which missed so many cases.

TABLE 7: MRCP VS INTRA-OPERATIVE (STANDARD)

\begin{tabular}{lllll}
\multirow{2}{*}{ MRCP findings } & \multicolumn{2}{l}{ Intra-operative findings } & \multicolumn{2}{l}{ Total } \\
\cline { 2 - 4 } & STONE PRESENT & STONE ABSENT & No. $(\%)$ & $\mathrm{X}^{2}$, \\
& No. $(\%)$ & No. $(\%)$ & $\mathrm{df}$ \\
& & & & P value \\
\hline STONE PRESENT & $110(84.61 \%)$ & $2(1.54 \%)$ & $112(86.15 \%)$ & 0.6666, \\
\hline STONE ABSENT & $4(3.08 \%)$ & $14(10.77 \%)$ & $18(13.85 \%)$ & 1, \\
\hline TOTAL & $114(87.69 \%)$ & $16(12.31 \%)$ & $130(100 \%)$ & -
\end{tabular}

Table 7 shows that result of the test test ie, MRCP not significantly differ from the truth ie, intra-operative findings. It mean that the test MRCP seemed to be suitable for diagnosing the disease. 
The sensitivity of MRCP was:(110/114)* $100=96.491 \%$,

Specificity was: $(14 / 16) \star 100 \quad=87.500 \%$,

Positive predictive value was: $(110 / 112) * 100 \quad=98.214 \%$,

And negative predictive value was; $(14 / 18) \star 100=77.777 \%$.

The sensitivity of the test MRCP reflected that the test seemed to be strong in detecting the disease ie, very low false negative would be produced by the test. For an emergency surgical problem like choledocholithiasis it should be the 'investigation of choice'.

TABLE 8: Distribution of participants as per USG (test test) vs MRCP (test test ). [ $\mathrm{N}=130]$.

\begin{tabular}{|c|c|c|c|c|}
\hline \multirow[t]{3}{*}{$\begin{array}{l}\text { USG report regarding CBD } \\
\text { stones }\end{array}$} & \multicolumn{2}{|c|}{$\begin{array}{l}\text { MRCP report regarding CBD } \\
\text { stones }\end{array}$} & \multirow[t]{3}{*}{$\begin{array}{l}\text { Total No. } \\
(\%)\end{array}$} & \multirow{3}{*}{$\begin{array}{l}\text { McNemar } \\
x^{2} \\
\text { DF, } \\
P \text { value }\end{array}$} \\
\hline & \multirow{2}{*}{$\begin{array}{l}\text { Positive (+), } \\
(\%)\end{array}$} & \multirow[t]{2}{*}{ Negative(-), (\%) } & & \\
\hline & & & & \\
\hline Positive (+) & 56 (98.25\%) & $01(1.75 \%)$ & 57 (100\%) & \multirow{2}{*}{$\begin{array}{l}53.070 \\
1 \\
>0.05\end{array}$} \\
\hline Negative (-) & $56(76.71 \%)$ & 17 (23.29 \%) & 73 (100\%) & \\
\hline Total & $112(86.15 \%)$ & 18 (13.85\%) & $130(100 \%)$ & _- \\
\hline
\end{tabular}

McNemar's Chi-Square Test (paired) $X^{2}=53.070$

DF $=1, P$ Value $>0.05$

Table $\mathbf{8}$ shows for comparison of diagnostic accuracy of the test test McNemar also called paired ChiSquare test was carried out considering the discordant values of cell b (false positive) \& c (false negative) 
McNemar $x^{2}=(b-c)^{2} /(b+c)$. It was revealed that the accuracy of the two test wasn't comparable rather they showed a statistically significant difference. It mean that the test with lower accuracy, shouldn't be the 'investigation of choice'.

Though, the MRCP is costly and complex in terms of applicability, but it should be the investigation of choice' unless otherwise indicated.

\section{Discussion}

Choledocholithiasis is most important complication of gall bladder stone disease which appears during the natural course of this disease.

\section{DEMOGRAPHICS:}

Incidence of choledocholithiasis has been found to be slightly higher in females compared with males in our study (2.08:1). In our study, the most common age group affected is between 41 to50 years. The mean age of the patients is $49.27 \pm 10.6028$ years. The incidence and prevalence of choledocholithiasis tends to increase with age. So the disease is essentially of the middle and elderly.

\section{SERUM BILIRUBIN LEVEL:}

Bilirubin level was raised in all patients except one, above $1.21 \mathrm{mg} / \mathrm{dl}$. The mean total bilirubin level was found to be $3.50 \pm 1.36 \mathrm{mg} / \mathrm{dl}$ (range 1.02 to $7.04 \mathrm{mg} / \mathrm{dl}$ ).

Impacted CBD stone was found intra-operatively in patients having bilirubin level more than $4.60 \mathrm{mg} / \mathrm{dl}$ in present study.Although jaundice can occur in the absence of stones, the degree of hyperbilirubinaemia correlates well with stones.

\section{SERUM ALKALINE PHOSPHATAGE LEVEL:}

Among the biochemical parameters studied, serum alkaline phosphatase has the highest sensitivity(65\%) in the diagnosis of choledocolithiasis. ${ }^{12}$

In present study, mean serum alkaline phosphatase (ALP) value was 381.56 $\pm 219.68 \mathrm{IU} / \mathrm{L}$ (range 156.04$1304.15 \mathrm{IU} / \mathrm{L})$ and all patients showed more than normal level (20-135IU/L). 


\section{ROLE OF USG IN DETECTING CBD STONE:}

Ultrasound was used as first investigation in all the patients suspecting of choledocholithiasis on the basis of laboratory findings. $68.2 \%$ of the patients have biliary dilatation in the USG. The sensitivity of ultrasonography for detecting biliary dilatation and choledocholithiasis as reported in various studies varies from 55 to $91 \% .{ }^{13}$

The role of ultrasonography in detection of common duct stones is less certain. The sensitivity deteriorates as one goes from the proximal to distal duct. The absence of surrounding bile makes the stone difficult to differentiate from the periductal structures ${ }^{14}$. However, the sensitivity of ultrasonography in detecting ductal dilatation which is an indirect evidence of CBD stones is very high. Hunt et al have showed that the probability of CBD stones increases as the duct size becomes larger ${ }^{15}$. Laing et al while evaluating 53 patients with obstructive jaundice got a sensitivity of $29 \%$, specificity of $91 \%$ and an accuracy of $55 \%{ }^{16}$

The accuracy of USG in detecting CBD stone is reported as ranging from $20-80 \%$ in many studies. ${ }^{17}$ In present study different parameters for USG was like following-

The sensitivity of USG was $49.12 \%$,

Specificity was $93.75 \%$,

Positive predictive value was $98.25 \%$, And negative predictive value was $20.55 \%$.

The sensitivity of the test (USG) reflected that it seemed to be weak in detecting CBD stone so many false negatives may be produced by the test .So it could not be the investigation of choice.

\section{ROLE OF MRCP IN DETECTING CBD STONE:}

MRCP was used for the confirmation of diagnosis in all the patients. In the present study accuracy of MRCP found out to be $95.38 \%$. Most of the large studies have reported that MRCP has sensitivity ranged from $81-100 \%$ and accuracy ranged from $89-100 \%$ for the diagnosis of choledocholithiasis. ${ }^{18}$

The sensitivity of MRCP was: $96.491 \%$,

Specificity was: $\quad 87.500 \%$,

Positive predictive value was:

$98.214 \%$,

Page $16 / 20$ 


\section{SURGICAL TECHNIQUE:}

In the present study type of surgery has been selected on the basis of number, size of CBD stones and diameter of the CBD. Majority of the patients have undergone open choledocholithotomy $(n=82$, $63.08 \%)$ Laparoscopic Choledocholithotomy was donein $(n=22,16.92 \%)$ patients. In 6 previously cholecystectomized patients only CBD exploration was done.4 out of rest 20 patients during open cholecystectomy operation CBD stone was found by palpation and CBD exploration was done.

Rest 16 patients no CBD stone was found and only cholecystectomy was done.

So,CBD stone was found in 114 patients out of total study population of 130 , i e $87.69 \%$.

In this present study intra-operative finding was considered as 'gold standard'.

There were some limitations in this study.

- The incidence and prevalence rate of choledocholithiasis among these populations was not studied previously. So this study may not reflect exact size of the disease in this particular Demographic area and also the national and international level.

- Some of CBD stones may pass during or before surgery, so exact figure may be missed.

- The investigation reports may be operator dependant. Some expert operator may give good quality of reports.So USG reports to some extent depends on operators.

\section{Conclusion:}

The role of ultrasonography in detection of common duct stones is less certain. The sensitivity deteriorates as one goes from the proximal to distal duct. The absence of surrounding bile makes the stone difficult to differentiate from the periductal structures. However, the sensitivity of ultrasonography in detecting ductal dilatation which is an indirect evidence of CBD stones is very high. The sensitivity of the test (USG) reflected that it seemed to be weak in detecting CBD stone so many false negatives may be produced by the test .So it could not be the investigation of choice. The sensitivity of the test(MRCP) reflected that the test seemed to be strong in detecting the disease ie, very low false negative would be produced by the test. For an emergency surgical problem like choledocholithiasis it should be the 'investigation of choice'. 


\section{Declarations}

FUNDING: No funding source/grant was available. No external fund was available. All investigations and treatment were done free of cost in the government teaching hospital named BSMCH,Bankura,WB,India.

Conflict of interest. The authors declare that they have no competing interests.

Ethical approval: Obtained from the Institutional Ethics Committee, BSMCH, Bankura, West Bengal, India. Approval letter (Memo No.BSMC/Aca/36 dt 02.01.18) is available for review by the editor of the journal. Written consents from individual patients were also obtained.Written informed consent for participation in the study was obtained where participants were children (under 16 years old) from their parent or guardian.

\section{References}

1. Mcfadden DW, Nigam Choledocholithiasis and cholangitis. In: Zinner Mj, Ashley SW. eds. Maingot's abdominal operaions.11th Edn. Mcgraw-Hill; 2007:865-879

2. Topal B, Van de Moortel M, Fieuws S, Vanbeckevoort D, Van Steenbergen W, Aerts R, et al. The value of magnetic resonance cholangiopancreatography in predicting common bile duct stones in patients with gallstone disease. Br J Surg 2003;90:42-7.

3. Duensing RA, Williams RA, Collins JC, Wilson SE. Managing choledocholithiasis in the laparoscopic era. Am J Surg 1995;170:619-21

4. Yang $\mathrm{MH}$, Chen $\mathrm{TH}$, Wang $\mathrm{SE}$, et al. Biochemical predictors for absence of common bile duct stones in patients undergoing laparoscopic cholecystectomy. Surg Endosc. 2008;22:1620-1624.

5. Jinfeng Z, Yin Y, Chi Z, Junye G. Management of impacted common bile duct stones during a laparoscopic procedure: A Retrospective Cohort Study of 377 Consecutive Patients. Int J Surg. 2016 Aug;32:1-5.

6. Yang $\mathrm{MH}$, Chen $\mathrm{TH}$, Wang $\mathrm{SE}$, et al. Biochemical predictors for absence of common bile duct stones in patients undergoing laparoscopic cholecystectomy. Surg Endosc. 2008;22:1620-1624.

7. Song $\mathrm{SH}$, Kwon $\mathrm{Cl}$, Jin SM, et al. Clinical characteristics of acute cholecystitis with elevated liver enzymes not associated with choledocholithiasis. Eur J Gastroenterol Hepatol. 2014;26:452-457.

8. Chavda, Vijay et al. Choledocholithiasis: An update on current evidence and practice. Medical Research Archives, [S.I.], v. 5, n. 2, feb. 2017. ISSN 2375-1924. 
9. Goyani B, Ukani B, Patel M, Shah B, Vadel M. Ultrasonography and magnetic resonance cholangiopancreatography correlation in patients with obstructive jaundice. Int J Med Sci Public Health 2015;4:1010-1014 .

10. Abdul samad sakijan,Maimunah atan,CHOLEDOCHOLITHIASIS: DIAGNOSIS BY ULTRASOUND .Med. J. Malaysia Vol. 42 No. 2 June 1987

11. Meyers WC, Jones RS.Development of the liver and biliary tract In: Meyers WC Jones RS (editors). Textbook of liver and biliary surgery. J .B. Lippincott Company 1990;(1);1-19.

12. Sugiyama M, Atomi Y. Endoscopic ultrasonography for diagnosing choledocholithiasis: a prospective comparative study with ultrasonography and computed tomography. Gastrointest Endosc1997;45(2):143-146

13. Liu TH, Consorti ET, Kawashima A, Ernst RD, Black CT, Greger PH, et al . The efficacy of magnetic resonance cholangiography for the evaluation of patients with suspected choledocholithiasis before laparoscopic cholecystectomy. Am J Surg 1999;178:480-4

14. Gross BH et al, Ultrasonic evaluation of Common Bile Duct stones: Prospective comparison with Endoscopic Retrograde Cholangiopancreatography, Radiology 1983; 146: 471-474.

15. Hunt DR, Reiter L, Scott AJ. Preoperative ultrasound measurement of bile duct diameter: Basis of selective cholangiography. Aust NZ J Surg 1990; 60: 189-192.

16. Laing FC et al. Choledocholithiasis and Cystic Duct obstruction: Difficult ultrasonographic diagnosis, Radiology 1983; 146: 475-479.

17. Ferrari FS, Fantozzi F, Tasciotti L, Vigni F, Scotto F, Frasci P. US, MRCP,CCT and ERCP: a comparative study in 131 patients with suspected biliary obstruction. Med Sci Monit 2005;11(3):8- 18.

18. Guibaud L, Bret PM, Reinhold C, Atri M, Barkun AN. Bile duct obstruction and choledocholithiasis: diagnosis with MR cholangiography. Radiology1995;197(1):109-115

\section{Figures}




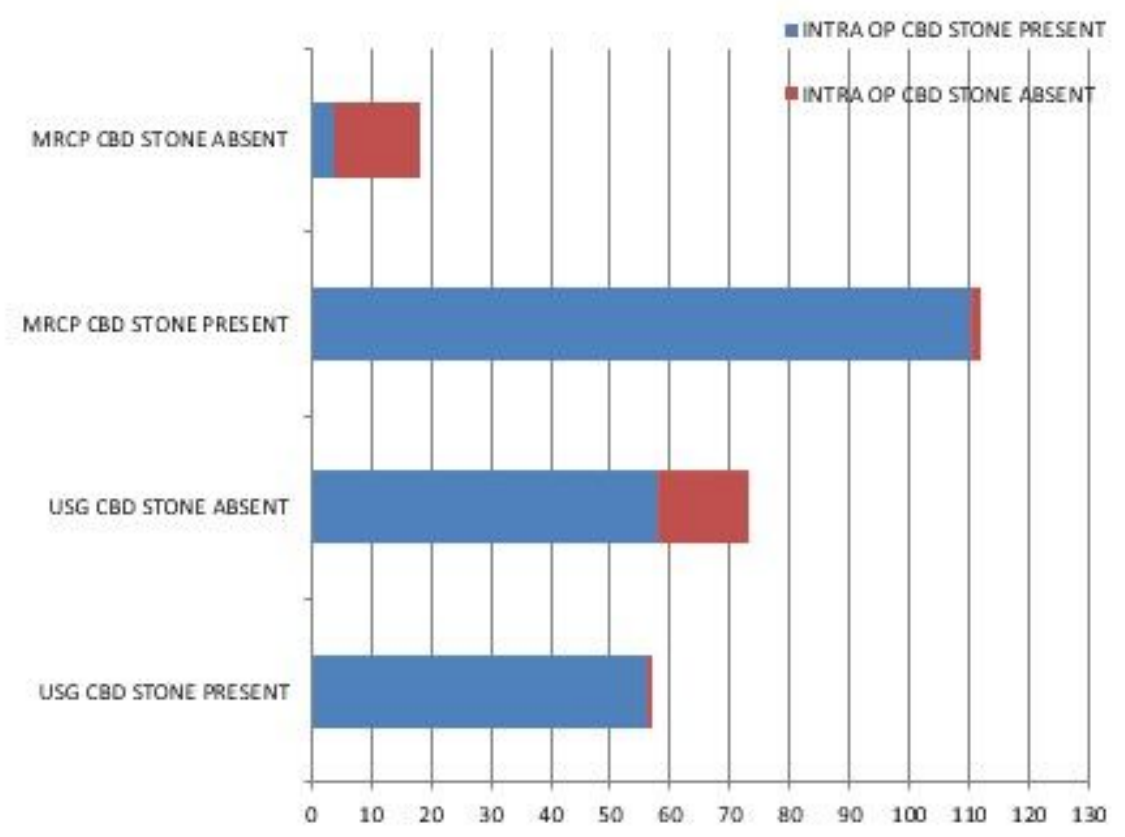

Figure 1

USG AND MRCP vs intra-operative finding. 